Session 3515

\title{
Planning and Design of a Water Distribution System with Practitioner and Student Interaction
}

\author{
Michael E. Mulvihill \\ Loyola Marymount University
}

\begin{abstract}
In the spring semester of 2002 the second semester senior level Water Resources Planning and Design course at Loyola Marymount University was substantially modified to make the course more student centered and practice oriented. The course was enhanced by including the involvement of several civil engineering practitioners. This involvement was motivated by ASCE's call for greater cooperation between students and professional practitioners in the educational process. In order to accomplish this, several LMU alumni who are intimately involved in the water industry were called upon to share their expertise. In this paper the elements of the course will be described and the outcomes including student feedback will be presented.
\end{abstract}

\section{Introduction}

The Water Resources Planning and Design course is a 14-week semester long course which meets twice per week for 75-minute sessions. In preparing for the Spring 2002 semester, it was apparent that the standard lecture course conducted in previous years would not satisfy the students' or instructor's needs. Since the students were within four months of graduation, the intent was to provide a transition from the classroom to the profession. It was time to give the students more control of their learning. The objective was to enhance student knowledge and satisfy the following LMU civil engineering ABET program outcomes in which students have:

A. The ability to design a system, component or process to meet desired needs

B. The ability to identify, formulate and solve engineering problems

C. The ability to communicate effectively

D. The broad education necessary to understand the impact of engineering solutions in a global and societal context

E. The knowledge of contemporary issues

F. The ability to use the techniques, skills and modern engineering tools necessary for engineering practice 


\section{Course Activities}

Course activities included:

- Instructor presentations

- Student preparation and presentation of water resource topics

- Interaction with professional practitioners

- Preliminary work on the design project

- Practitioner instruction on the use of $\mathrm{H}_{2} \mathrm{ONET}$ software

- Design of a water distribution system and preparation of a formal report

\section{Instructor Presentations}

During the first part of the course, instruction on surface water hydrology, an introduction to the components of water distribution systems and a review of the Hardy Cross method were presented by the instructor.

\section{Student Presentations}

Students were asked to select two topics of interest from the three water resources engineering textbooks listed in the references. Students were then paired based on the topics selected and each group prepared and presented a lecture to the class using a PowerPoint presentation. The topics selected by the students for presentation were: reservoir sediment, reservoir and stream flow routing, storm water control, flood damage mitigation, planning for water resource development, water withdrawals and uses, irrigation, water law, hydroelectric power, engineering economy for water resources and river navigation.

\section{Interaction with Professional Practitioners}

Five practitioners participated in this course. The first two provided first hand knowledge of the water resources, the current problems and the proposed solutions for the Southern California region. They gave students an awareness of the political and social issues associated with obtaining and providing water to meet the needs of a highly populated semi-arid region. The third practitioner conducted a field trip to the water distribution facilities of a nearby city. The fourth presenter provided insight on the design of distribution systems from the viewpoint of an engineering consultant. The final practitioner instructed the students in the use of $\mathrm{H}_{2} \mathrm{ONET}$ and served as a consultant during the design project.

The first practitioner was Mr. Steven Arakawa (class of 1980). Mr. Arakawa, manager of the water resources management group of the Metropolitan Water District (MWD) of Southern California, presented an overview of Southern California's water resource issues. MWD provides water to 26 cities and water agencies in six counties covering a 5,200 square mile area. It services 17 million people and a regional economy of over 600 billion dollars. Growth is expected to continue at a rate of 220,000 people per year. MWD imports water from the Colorado River and Northern California as well as utilizing groundwater. Mr. Arakawa's presentation included the history of water supply for Southern California; the current social, 
political and management issues; and what is expected in the future. He stressed the need for a comprehensive water management plan. MWD's plan addresses the need for maintaining existing supplies for reliability while addressing water quality issues. In addition, the plan calls for investment in feasible conservation and recycling programs. Additional storage facilities are planned in order to store excess imported water during wet years for use during dry years. Water transfers from agricultural to urban use are currently being investigated. This presentation provided an excellent articulation of the water resources available, the future needs and the management approach being implemented to meet those needs.

The second practitioner was Mr. Martin Adams (class of 1984). Mr. Adams, managing engineer for the Los Angeles Department of Water and Power's planning and project management group, presented an overview of the largest municipal utility which provides water and power service to 3.8 million people. The DWP has over 700,000 service connections and the water distribution system contains 100 service zones with distribution pipes as large as 102 inches in diameter. DWP water sources are imported water from Owens Valley, groundwater and MWD water. The driving issues facing the DWP are infrastructure maintenance, water quality/ regulatory compliance, environmental mitigation and future water supplies. For the next ten years $\$ 300$ million per year will be invested in infrastructure. This includes covering or replacing ten remaining open reservoirs and replacement of 175,000 ft. of pipe per year. Additional reclaimed water will be developed for non-potable uses and research will continue on the feasibility of desalination. Mr. Adams also provided information on water use factors and fire flows.

The above two presentations provided an overview of water supply sources and information on the management of water resources in Southern California. Both presenters stressed the need to meet water quality standards and comply with the many water quality regulations existing today. They also indicated that there was much work to be accomplished and a career in the water industry would be challenging and rewarding.

Next, the students toured the Culver City water distribution system. Mr. Michael Gutierrez, (class of 1978) from the Southern California Water Company, gave the students an overview of how a small private water company supplies and maintains the distribution systems for several small cities. He presented a schematic of the Culver City distribution system and then led a tour of a pump station and the equalizing storage tanks in the city. This provided the students with physical examples of components they would utilize in designing a distribution system. Following this tour, the design of a water distribution system for a small expanding city was assigned.

As an aid to the design process, Mr. Aaron Gutierrez, a consulting engineer with Psomas, gave the fourth practitioner presentation. Mr. Gutierrez has considerable experience designing distribution systems for new communities. His perspective was from the point of view of a consulting engineer working for a client. He stated that the key elements that must be considered while designing systems are cost, client satisfaction, reliability, and construction and maintenance efficiency. He provided advice on how to approach and complete the tasks necessary to arrive at a final design. His firm uses the $\mathrm{H}_{2} \mathrm{ONET}$ design software and suggested that learning to use it would give the students a head start when looking for a position in the water supply field. He also volunteered to serve as a technical advisor to the students.

Proceedings of the 2003 American Society for Engineering Education Annual Conference \& Exposition Copyright 2003, American Society for Engineering Education 
The final participating practitioner, Mr. Paul Hauffen, (class of 1995), director of engineering education at Montgomery Watson Harza Consulting Engineers, introduced the $\mathrm{H}_{2} \mathrm{ONET}$ computer design software and served as a consultant on its use. He facilitated the students' use of the program by working with them in the civil engineering computer lab. He was on campus several times to aid them. He was also available by e-mail and telephone, and the students took full advantage of this.

\section{Water Distribution Design Project}

The students were asked to assume that they were members of a consulting firm assigned the task of designing a water distribution system for a small expanding hypothetical city. The following is a description of the project:

For many years, the town of Foxville was nothing more than a typical one-gas station hamlet on a highway about 50 miles south of a large metropolitan area. The few residents were either employees of farmers in the immediate area or owners of small businesses catering to the needs of highway travelers. Water supply and sewerage were handled on an individual basis by private wells and septic tanks, respectively.

Recently, a real estate development company obtained an option for 150 acres of reasonably level farmland between the town and the highway and announced its intention to develop an industrial park which they estimated would ultimately employ people in approximately the following categories: $15 \%$ professional, $30 \%$ technician, $30 \%$ skilled labor, $15 \%$ clerical and $10 \%$ semi-skilled labor. This influx of new residents is expected to give rise to a number of new businesses. Also, it was recently announced that a 600-acre tract northeast of town was purchased for a retirement village.

Faced with this sudden growth, the residents of Foxville have incorporated themselves into a city. A water district has been formed for the purpose of providing water service, sewage collection and treatment facilities not only for the incorporated city but also for future areas that may be annexed.

In addition to this description, three maps were provided showing the street layout for the existing town, the details of the town's proposed expansion and a topographic map of the area. These were augmented by a description of the existing and expanded land use. Water will be supplied from a regional canal that passes by the southeastern corner of town. A pump station will be required to provide sufficient pressure to the distributed water. The topography shows a hill just northwest of town that provides a location for an equalizing storage tank for flow variations and storage for fire protection.

In preparation for the design, students contacted various water departments in California to obtain information on water use and current design practices. Fire flow information was obtained from the fire department. 
The students worked in groups of two with the exception of three students who worked individually. Each group started by determining the land use for each sub area. They then applied water use factors to determine water requirements. At this point a first cut at pipe sizes was taken and pumps and a storage tank were added to the system. With the data assembled the $\mathrm{H}_{2} \mathrm{ONET}$ program was run to evaluate pressures throughout the system. Since the students were well versed in the use of AUTOCAD, using $\mathrm{H}_{2}$ ONET was a natural extension for them. However, there was still a learning curve both on how to utilize the program and how to evaluate the results and make adjustments to the system design. The program made it easy to conduct "what if" questions and compare results of changes in pipe sizes. Several scenarios were run such as Q-maximum day plus fire flow in the city, Q-average day and Q-max day plus fire flow at the industrial park. These were evaluated and adjustments were made until a final design was obtained. The students obtained a full realization of the many factors that must be considered in the design process. They appreciated the necessity to make modifications. The final product was a formal engineering report documenting each group's design. This was the culmination of many hours of effort.

\section{Course Activities Vis-à-vis Program Outcomes}

The intent of this course was to engage the students in activities that would better prepare them for professional practice. Each course activity satisfied one or more of the department's program outcomes. The instructor's presentations were designed to enhance the student's knowledge

(Outcome B). Student presentations enhanced their ability to communicate effectively (Outcome C). Interaction with professionals improved student knowledge and provided an awareness of contemporary issues (Outcomes D and E). Preliminary work on the design project improved the ability of the students to effectively solve problems and develop creative designs (Outcomes A, $\mathrm{B}$ and F). Practitioner instruction on the use of $\mathrm{H}_{2} \mathrm{ONET}$ software increased student knowledge and improved problem-solving skills (Outcomes A and F). The design of the water distribution system enhanced the students' problem solving and design skills (Outcomes A, B and F). The preparation of the final formal engineering report provided the opportunity to improve their written communication ability (Outcome C).

\section{Student Feedback}

Student reaction to this course, which was solicited after the students were employed or in graduate school, was mostly positive. Specific student comments were:

"The course was a very useful learning environment for me. A broad introduction to water distribution and master planning was given by the instructor and professional employees of water agencies, utilities and corporations."

"Practitioners' presentations were beneficial for the class because students could learn about the real working environment, different projects, and some interesting details about California's water distribution system (this was especially helpful for the City and County job interviews)."

"It was great to have engineers from past programs share their experiences and it provided the opportunity for the students to network with them."

Proceedings of the 2003 American Society for Engineering Education Annual Conference \& Exposition Copyright 2003, American Society for Engineering Education 
"During the field trip to the Culver City water facilities, the students were presented with a real world view of what was before only seen on paper as a schematic drawing or on a chalkboard in class."

"Although it provided the opportunity for students to practice their presentation skills, I think the class would be more beneficial if the topics were taught by the professor."

"I thought the presentations that the students gave in class were not as effective as those presented by the instructor. Since our classmates were giving the presentations most people did not pay close attention."

"Learning how to use $\mathrm{H}_{2} \mathrm{ONET}$ was a definite plus. It showed us exactly what kind of work goes into designing a water system for a city. I always felt that working on a project is more educational than taking a test because the experience stays with you longer."

"Learning a new computer program is beneficial, however I think it would be better if it was more structured."

"The final design and formal report were great as it enabled me to understand how to use the $\mathrm{H}_{2} \mathrm{ONET}$ program. Even though the project was useful, more technical knowledge could have been taught to enable students to understand the theory."

"In terms of the design project, we should have started earlier in the semester so that we would not have been rushing at the end."

"I really enjoyed $\mathrm{H}_{2} \mathrm{ONET}$. Maybe it's because I spent so much time learning the program, but I think it's because I enjoyed it that I spent so much time learning it. It was helpful that Paul Hauffen gave us a 'crash course' on this program."

"Through the use of $\mathrm{H}_{2} \mathrm{ONET}$ the ability to associate the 'numbers' or results produced through your model and simulation with the physical matter in the real world has been greatly enhanced. The water cannot be physically touched but the numbers can easily be understood. There is ample opportunity to be creative. There are many components that can be assumed or changed and modeled differently to compare scenarios and situations that in the past had to be solved through many drastically long hand calculations."

"Even though the project was useful, more technical knowledge or theoretical education could have been taught. Having the ability to use $\mathrm{H}_{2}$ ONET is important but understanding the mechanics is also important, especially for students who intend to pursue a graduate degree."

"The writing of the report was good for me. Every day at work I see RFPs, marketing proposals, reports and studies going out and they look good. Students should learn to take pride in what their reports look like, as well as the content in them. Overall, I thought this was a great project and it really prepared me for the work world in terms of how to put together a professional report." 
"The report might have had an unnecessary amount of writing."

"Overall for the class I would suggest more defined time frames for all the assignments and more serious student presentations. Also, a more structured grading system would be helpful."

\section{Conclusions}

Upon reflecting on the content of the course and the student comments, several modifications are suggested for improving the effectiveness of the course. These modifications would include: additional lectures by the instructor, reduction of the number of student presentations, instructor input prior to student presentations, an earlier start on the design project and a more structured environment for learning how to use $\mathrm{H}_{2} \mathrm{ONET}$. Both the students and the instructor appreciated the practitioners' presentations and the assistance they provided for the design project. Students were quite satisfied with their final results and report. However, there were some frustrations in learning the program and implementing it. The students handled this in a professional manner and developed a clearer idea of what it takes to perform in the profession. It was especially rewarding to observe the growth in their capabilities and their development as they prepared to launch their professional careers.

\section{Acknowledgement}

Special thanks go to the professional engineers who volunteered their time to enhance the professional deve lopment of our students.

\section{References}

Linsley et al, Water Resources Engineering, Fourth edition, McGraw-Hill Inc, New York, 1992.

Mays, Water Resources Engineering, First edition, John Wiley \& Sons Inc, New York, 2001.

Wurbs and James, Water Resources Engineering, Prentice Hall, New Jersey, 2002.

Loyola Marymount University, ABET EC 2000 Program Self-Study Report, College of Science and Engineering, Department of Civil Engineering, June 2000.

Southern California Water Company, ISO System Report, Culver City System March 1997, prepared by ASL consulting Engineers, Pasadena CA.

Los Angeles Department of Water and Power, Design Guidelines for Gravity and Pump Systems 1997.

$\mathrm{H}_{2}$ ONET Analyzer Version 3.x Users Guide, MW Soft, Inc., 2001.

Proceedings of the 2003 American Society for Engineering Education Annual Conference \& Exposition Copyright 2003, American Society for Engineering Education 
MICHAEL E. MULVIHILL

Professor Mulvihill earned his Ph.D. at the University of California Los Angeles. He has taught a variety of courses at Loyola Marymount University in the Civil Engineering department over the past 37 years. He also serves as advisor for all freshman engineering students. His ASEE activities include service as chair of the Freshman Programs Division and a member of the Civil Engineering Division.

Proceedings of the 2003 American Society for Engineering Education Annual Conference \& Exposition Copyright 2003, American Society for Engineering Education 